\title{
HYDROCOLLOID DRESSING APPLICATION IN THE TREATMENT OF CHRONIC WOUNDS AND RELATION TO QUALITY OF LIFE
}

\author{
Dunja Jurić Vukelić ${ }^{1}$ and Jelena Jurić ${ }^{2}$ \\ ${ }^{1}$ University of Zagreb, Centre for Croatian Studies, Zagreb; \\ ${ }^{2}$ Dr. Ivo Pedišić General Hospital, Sisak, Croatia
}

\begin{abstract}
SUMMARY - The aim was to analyze relationship between the application of hydrocolloid dressings in the treatment of chronic wounds and relation to the patient quality of life. The study included 33 vascular outpatients. The authors constructed a questionnaire for assessing the level of daily functional impairment and the quality of life. Participants assessed the level of pain, level of decreased independence in daily activities, level of sleep disturbance, difficulties with keeping hygiene, and level of odor caused by a chronic wound. Significant differences were found in all aspects of chronic wound interference with the quality of life after the application of hydrocolloid dressings: level of pain ( $t$ $(23)=4.14)$, independence in everyday activity $(\mathrm{t}(23)=5.01)$, interference with sleep $(\mathrm{t}(23)=3.89)$, hygiene $(\mathrm{t}(23)=3.00)$ and an unpleasant odor $(\mathrm{t}(23)=3.66)(\mathrm{p}<0.01$ all $)$. According to the physician's assessment, the treatment of chronic wound with hydrocolloid dressing significantly improved patient condition in $84.8 \%$ of cases. The application of hydrocolloid dressings led to reduction in all of the examined symptoms, thus having contributed to better quality of life in study patients.
\end{abstract}

Key words: Bandages, hydrocolloid; Quality of life; Wounds and injuries; Wound healing

\section{Introduction}

Chronic wound care has an important role in medical treatment of elderly patients. There are four types of chronic wounds: bedsore, arterial ulcer, venous ulcer, and neuropathic ulcer ${ }^{1}$. Risk factors are poor mobility and old age characterized by a high level of comorbidity ${ }^{2}$. Every chronic wound is specific and requires careful and long-term treatment ${ }^{3}$. The first step in developing an effective therapeutic approach implies an accurate diagnosis of the cause of wound ${ }^{4}$. In addition, appropriate nutrition and prevention of wound infection are necessary for successful healing of the wound. It is important to accentuate the need of cooperation of healthcare professionals as a condition for successful

Correspondence to: Dunja Jurić Vukelić, mag. psych., Centre for Croatian Studies, Borongajska cesta 83d, HR-10000 Zagreb, Croatia

E-mail: dunja.juric@gmail.com

Received November 4, 2015, accepted June 26, 2017 therapy ${ }^{5}$. According to previous research, efficiency of therapy depends on the expectancy of positive outcomes and to a significant extent confidence in physicians and nurses ${ }^{6}$. However, the most important factor for successful healing of a wound is prompt and accurate treatment. The right choice of hydrocolloid and alginate dressing, wherein it is important to take into account the type of chronic wound, the amount of secretion, and the patient's assessment of the level of pain, are crucial. Wound dressing with ionic silver tends to be particularly effective for infected wounds ${ }^{7}$.

High cost is often pointed out as an argument against the application of hydrocolloid dressings. However, faster healing, lower frequency of bandaging, lower level of pain, higher assessment of the quality of life, and the fact that hydrocolloid dressings are the only therapy which can lead to complete healing ${ }^{8}$, indicate higher long-term cost-effectiveness of hydrocolloid dressings versus former approaches to the treatment of chronic wounds. This information indicates 
the need of a more elaborate longitudinal research of this relatively new therapy ${ }^{7}$.

Descriptive research of patient experiences with chronic wounds shows that the greatest difficulties in everyday functioning are caused by high levels of pain ${ }^{6}$, which highly correlates with the high level of psychosocial stress and low assessment of the quality of life 9 .

Chronic wounds pose major burden on the patients and have negative psychological, physical and social repercussions for their health, well-being and quality of life. Pain is identified as the biggest problem, which significantly decreases the quality of life; additionally, anxiety results from the feeling that the patient is burden to the others. Besides chronic pain, studies have pointed to numerous restrictions in physical and social aspects of life, emotional disturbances such as anxiety, frustration, anger and depression, as well as low subjective well-being ${ }^{10}$.

In the risk group of elderly patients, the quality of life is a substantial aspect that predicts outcome of therapeutic protocols. Consuetudinary measurements of comorbidity and mortality do not provide a comprehensive overview of the health status including psychophysical, emotional and functional well-being, so it is conducive to complement them with patient perception of the probability of recovery ${ }^{11,12}$.

\section{Patients and Methods}

\section{Patients}

Thirty-three vascular outpatients enrolled in the exploratory study included patients with type 2 diabetes mellitus with open foot ulcer and patients with ulcers of neuropathic, ischemic or neuroischemic causes. There were $75.8 \%$ of female and $24.2 \%$ of male patients, mean age 71.83 (range, 49-86) years. The study was conducted with either the paper-pencil method or face-to-face questionnaire in patients that were not able to independently complete the questionnaire.

\section{Instruments}

For the purpose of this study, the authors constructed a questionnaire for assessing the level of daily functional disruption and quality of life impairment caused by chronic wound. Study patients assessed the level of pain caused by chronic wound, level of decreased independence in everyday activity performance, how much their sleep was disturbed, difficul- ties with hygiene, and level of odor caused by chronic wound. Additionally, the patients expressed their confidence in positive outcomes of therapy. Responses were estimated on the 7-point Likert scale, wherein point 1 referred to minimum and point 7 to maximum. Individual patient's password was marked on every questionnaire for the purpose of repeated measurements. Demographic data (age and sex), time of the appearance of chronic wound, and type of dressing applied were also recorded. At repeated measurements, physician additionally assessed whether or not the treatment of chronic wound by hydrocolloid dressing significantly improved the patient's condition.

The following hydrocolloid dressings were applied in chronic wound treatment: Aquacel $\mathrm{Ag}$, combination of Aquacel $\mathrm{Ag}$ and Granugel, and combination of Aquacel Ag, Granugel and Aquacel Ag Foam (Table 1).

Table 1. Types of hydrocolloid dressing applied

\begin{tabular}{|l|l|l|l|}
\hline & $\mathrm{n}$ & $\%$ & $\begin{array}{l}\text { Cumulative } \\
\text { percent }\end{array}$ \\
\hline Aquacel Ag & 14 & 42.4 & 42.4 \\
$\begin{array}{l}\text { Aquacel + Granugel } \\
\text { Aquacel + Granugel } \\
\text { + Aquacel Ag Foam } \\
\text { Total }\end{array}$ & 14 & 42.4 & 84.8 \\
\hline
\end{tabular}

\section{Procedure}

The present study was conducted from October 2012 until June 2013, during patient follow-up visits to Dr. Ivo Pedišić General Hospital, Sisak. The physician read instructions with noted information on data anonymity and voluntary participation. The patients signed the informed consent form and completed the questionnaire. Treatment of chronic wounds with hydrocolloid dressings started at this point of examination. The same procedure with completing the questionnaire was repeated during one of the next followup visits at one or several months later. The questionnaire contained the same questions as on the first occasion, except for demographics and with the addition of physician's assessment of the patient's condition. For the purpose of maintaining anonymity, the two questionnaires were linked with the patients' individual passwords. 
Table 2. Total variance explained after Varimax rotation

\begin{tabular}{|l|l|l|l|l|l|l|}
\hline \multicolumn{6}{|l|}{ Initial Eigen values extraction sums of squared loadings } \\
\hline Component & Total & \% of variance & Cumulative \% & Total & \% of variance & Cumulative \% \\
\hline 1 & 2.86 & 47.67 & 47.67 & 2.25 & 37.56 & 37.56 \\
2 & 1.43 & 23.90 & 71.57 & 2.04 & 34.01 & 71.57 \\
3 & 0.68 & 11.41 & 82.98 & & & \\
4 & 0.44 & 7.31 & 90.29 & & & \\
5 & 0.37 & 6.23 & 96.52 & & & \\
6 & 0.21 & 3.48 & 100.00 & & & \\
\hline
\end{tabular}

Table 3. Rotated component matrix

\begin{tabular}{|c|c|c|}
\hline & \multicolumn{2}{|l|}{ Factor } \\
\hline & $\begin{array}{l}1-\text { Physical } \\
\text { manifestations }\end{array}$ & 2-Hygiene \\
\hline $\begin{array}{l}\text { 1. To which extent does } \\
\text { the chronic wound } \\
\text { cause pain? }\end{array}$ & 0.92 & \\
\hline $\begin{array}{l}\text { 2. To which extent does } \\
\text { the chronic wound } \\
\text { decrease independence } \\
\text { in everyday activities? }\end{array}$ & 0.68 & \\
\hline $\begin{array}{l}\text { 3. To which extent does } \\
\text { the chronic wound } \\
\text { interfere with your } \\
\text { sleep? }\end{array}$ & 0.89 & \\
\hline $\begin{array}{l}\text { 4. To which extent does } \\
\text { the chronic wound } \\
\text { interfere with } \\
\text { hygiene? }\end{array}$ & & 0.69 \\
\hline $\begin{array}{l}\text { 5. To which extent does } \\
\text { the chronic wound } \\
\text { cause an odor? }\end{array}$ & & 0.85 \\
\hline $\begin{array}{l}\text { 6. Level of confidence } \\
\text { in a positive outcome } \\
\text { of therapy }\end{array}$ & & -0.79 \\
\hline
\end{tabular}

\section{Results}

\section{Factor structure and instrument reliability}

For the purpose of assessing psychometric preconditions for appropriateness of correlation matrix for factor analysis, the authors conducted KMO and Bartlett's test. Bartlett's test was significant $\left(\chi^{2}=47.24, \mathrm{p}<0.01\right)$ and $\mathrm{KMO}$ had a score of 0.70 , which indicated convenience of the correlation matrix for factor analysis. Factor analysis results clearly indicated the existence of two
Table 4. Reliability statistics

\begin{tabular}{|l|l|}
\hline & Cronbach $\alpha$ \\
\hline Factor 1 & 0.82 \\
Factor 2 & 0.72 \\
\hline
\end{tabular}

factors with Eigen values 2.25 and 2.04. The first factor explained $37.56 \%$ and the second factor explained $34.01 \%$ of the manifest variables variance. Both factors together after Varimax rotation explained $71.57 \%$ of the manifest variables variance (Table 2 ).

Table 3 shows saturation of items after Varimax rotation. Items 1, 2 and 3, measuring the level of pain caused by chronic wound, the level of decreased independence in everyday activities, and the level of interference with sleep were saturated by factor 1 , which can be described as physical manifestations. Items 4, 5 and 6, measuring the level of interference with hygiene caused by chronic wound and the level of odor caused by chronic wound, were saturated by factor 2 , which can be described as hygiene.

Cronbach $\alpha$ was calculated to determine reliability of the instruments applied according to the factors obtained. The coefficients are shown in Table 4. For the subscale of physical manifestations, Cronbach $\alpha$ was 0.82 , and for the subscale of hygiene 0.72 (Table 4). These results indicated good reliability of the scale.

\section{Comparison of the results recorded on the initial and repeated questionnaire administration}

The highest scores were recorded for the extent of chronic wound interfering with hygiene, on both initial and repeated questionnaire administration (M1=6.42 vs. M2=5.67). Assessment of the level of odor caused by chronic wound was also high (M1=5.13 vs. M2=3.88), as well as the level to which chronic 
Table 5. Difference between results of initial and repeated questionnaire administration

\begin{tabular}{|l|l|l|l|l|l|l|l|}
\hline & \multicolumn{5}{|l|}{$1^{\text {st }}$ administration } & \multicolumn{3}{|l|}{$2^{\text {nd }}$ administration } \\
\cline { 2 - 7 } & $\mathrm{N}$ & $\mathrm{M}$ & $\mathrm{SD}$ & $\mathrm{M}$ & $\mathrm{SD}$ & $\mathrm{Sig}$. \\
\hline $\begin{array}{l}\text { 1. To which extent does the chronic wound } \\
\text { cause pain? }\end{array}$ & 33 & 4.00 & 1.79 & 2.67 & 1.31 & $\mathrm{t}(23)=4.14, \mathrm{p}<0.01$ \\
$\begin{array}{l}\text { 2. To which extent does the chronic wound } \\
\text { decrease independence in everyday } \\
\text { activities? }\end{array}$ & 33 & 4.88 & 1.15 & 3.88 & 1.39 & $\mathrm{t}(23)=5.01, \mathrm{p}<0.01$ \\
$\begin{array}{l}\text { 3. To which extent does the chronic wound } \\
\text { interfere with your sleep? }\end{array}$ & 33 & 3.63 & 1.71 & 2.04 & 1.30 & $\mathrm{t}(23)=3.89, \mathrm{p}<0.01$ \\
$\begin{array}{l}\text { 4. To which extent does the chronic wound } \\
\text { interfere with hygiene? }\end{array}$ & 33 & 6.42 & .50 & 5.67 & 1.24 & $\mathrm{t}(23)=3.00, \mathrm{p}<0.01$ \\
$\begin{array}{l}\text { 5. To which extent does the chronic wound } \\
\text { cause an odor? }\end{array}$ & 33 & 5.13 & 1.48 & 3.88 & 1.73 & $\mathrm{t}(23)=3.66, \mathrm{p}<0.01$ \\
\hline
\end{tabular}

$\mathrm{N}$ = total number of patients; $\mathrm{M}=$ mean; $\mathrm{SD}$ = standard deviation; Sig. = significance

Table 6. Physician's assessment of recovery

\begin{tabular}{|l|l|l|}
\hline & Yes & No \\
\hline $\begin{array}{l}\text { Treatment of chronic wound with } \\
\text { hydrocolloid dressing has significantly } \\
\text { improved patient condition }\end{array}$ & $84.8 \%$ & $15.2 \%$ \\
\hline
\end{tabular}

Table 7. Correlation between the level of confidence in positive therapy outcome and physician's assessment of recovery

\begin{tabular}{|c|c|c|}
\hline & & $\begin{array}{l}\text { Treatment of chronic wound } \\
\text { with hydrocolloid dressing } \\
\text { has significantly improved } \\
\text { patient condition }\end{array}$ \\
\hline \multirow{3}{*}{$\begin{array}{l}\text { Level of } \\
\text { confidence } \\
\text { in positive } \\
\text { outcome } \\
\text { of therapy }\end{array}$} & $\begin{array}{l}\text { Pearson's } \\
\text { correlation }\end{array}$ & $0.76^{* *}$ \\
\hline & $\begin{array}{l}\text { Sig. } \\
\text { (2-tailed) }\end{array}$ & 0.000 \\
\hline & $\mathrm{N}$ & 33 \\
\hline
\end{tabular}

**Correlation significant at the 0.01 level (2-tailed); Sig. = significance; $\mathrm{N}=$ total number of patients

wound reduced independence in everyday activities ( $\mathrm{M} 1=4.88$ vs. $\mathrm{M} 2=3.88$ ).

After comparing the initial and repeated examination, significant differences were found in all aspects of the chronic wound interference with the quality of life: level of pain $(t \quad 23)=4.14, p<0.01)$, decreased independence in everyday activities $(t(23)=5.01, p<0.01)$, sleep ( $\mathrm{t}(23)=3.89, \mathrm{p}<0.01)$, hygiene $(\mathrm{t}(23)=3.00$, $\mathrm{p}<0.01)$ and odor $(\mathrm{t}(23)=3.66, \mathrm{p}<0.01)$. The changes recorded in all these items indicated reduction of the symptoms as reported by the questionnaire (Table 5).

Table 6 shows that, according to the physician's assessment, the treatment of chronic wound with hydrocolloid dressing significantly improved patient condition in $84.8 \%$ of cases, with no improvement reported in $15.2 \%$ of cases.

Point-biserial correlation indicated a significant positive correlation between the level of confidence in positive outcome of treatment and physician's assessment of recovery $\left(r=0.76^{* *}, p<0.01\right)$ (Table 7$)$.

\section{Discussion}

Correlation matrix was tested and factor analysis was found to be valid. Factor analysis clearly indicated the existence of two latent variables, i.e. physical manifestations and hygiene. These results, as well as the high reliability of the instrument, indicated practical benefits of the quality of life questionnaire in patients with chronic wounds. Considering the relatively new studies tackling the issue, on designing the questionnaire emphasis was put on the conditions of outpatient treatment and limited time a physician has available for each individual patient. Future studies should elaborate the construct of the quality of life in patients with chronic wounds more specifically and with more detail.

The items included in the first latent variable referred to the level of pain, level of decreased indepen- 
dence caused by chronic wound, and level of chronic wound interference with sleep. Second latent variable included the level of interference with hygiene and odor caused by chronic wound.

Our patients emphasized difficulties with hygiene and odor as the major obstacles in everyday functioning. These results do not comply with expectations of high level of pain as a major obstacle ${ }^{6,9}$, which our patients reported as the third interfering factor. The level of decreased independence in everyday activities was also assessed as high. The patient clinical data confirmed the expected risk factors of older age, poor mobility, and high level of comorbidity ${ }^{2}$.

Comparison of the initial and repeated questionnaire results obtained before and after the application of hydrocolloid dressings showed significant difference in terms of higher quality of life. The level of pain caused by chronic wound was assessed significantly lower and the level of independence significantly higher. Quality of sleep and hygiene were estimated as better on repeated examination. In similar researches, the results are uneven in terms of the quality of life. Some researchers report the absence of difference in the quality of life ${ }^{13,14}$, whereas others report a significant effect on the quality of life $\mathrm{e}^{15,16}$. We believe that positive changes in the quality of life correlate with improvement in physical condition, although the small sample size limited statistical comparison between the patients whose progress was estimated by the physician as significant and those without such improvement.

In addition to the confirmed benefits of lower frequency of bandaging and faster healing of the wound, the authors consider that the results of improved quality of life with the application of hydrocolloid dressings indicated usefulness of hydrocolloid dressings in comparison with other treatments of chronic wounds currently in use.

\section{Conclusion}

The present study confirmed the expected high level of factors that decrease the quality of life and correlate with chronic wounds, i.e. high level of pain, decreased independence in everyday activities, interference with sleep and hygiene, and odor. We found reduction in every examined factor after the application of hydrocolloid dressings, associated with a higher quality of life. These results contribute to the justification of using hydrocolloid dressings as an optimal treatment of chronic wounds.
Appendix 1. Quality of life questionnaire

\section{$1^{\text {st }}$ administration}

Password:

Age:

Sex: M F

Period between appearance of chronic wound and start of treatment:

Type of chronic wound and type of dressing applied:

In the following 5 questions, please estimate your answer on a scale from 1 to 7 . Answer 1 means minimal, and answer 7 means maximal.

To which extent does the chronic wound:

1) cause pain?

$\begin{array}{lllllll}1 & 2 & 3 & 4 & 5 & 6 & 7\end{array}$

2) reduce your independence in everyday activity? $\begin{array}{lllllll}1 & 2 & 3 & 4 & 5 & 6 & 7\end{array}$

3) interfere with your sleep?

$\begin{array}{lllllll}1 & 2 & 3 & 4 & 5 & 6 & 7\end{array}$

4) interfere with your hygiene?

$\begin{array}{lllllll}1 & 2 & 3 & 4 & 5 & 6 & 7\end{array}$

$5)$ cause an unpleasant odor?

$\begin{array}{lllllll}1 & 2 & 3 & 4 & 5 & 6 & 7\end{array}$

Level of confidence in positive outcome of therapy:

$\begin{array}{lllllll}1 & 2 & 3 & 4 & 5 & 6 & 7\end{array}$

\section{$2^{\text {nd }}$ administration}

In the following 5 questions, please estimate your answer on a scale from 1 to 7 . Answer 1 means minimal, and answer 7 means maximal.

To which extent does the chronic wound:

6) cause pain?

$\begin{array}{lllllll}1 & 2 & 3 & 4 & 5 & 6 & 7\end{array}$

7) reduce your independence in everyday activity?

$\begin{array}{lllllll}1 & 2 & 3 & 4 & 5 & 6 & 7\end{array}$

8) interfere with your sleep?

$\begin{array}{lllllll}1 & 2 & 3 & 4 & 5 & 6 & 7\end{array}$

9) interfere with your hygiene?

$\begin{array}{lllllll}1 & 2 & 3 & 4 & 5 & 6 & 7\end{array}$

10) cause an unpleasant odor?

$\begin{array}{lllllll}1 & 2 & 3 & 4 & 5 & 6 & 7\end{array}$

Level of confidence in positive outcome of therapy:

$\begin{array}{lllllll}1 & 2 & 3 & 4 & 5 & 6 & 7\end{array}$

\section{Physician's assessment}

Treatment of chronic wound with hydrocolloid dressing significantly improved patient condition.

Yes

No 


\section{References}

1. Paul J. A cross-sectional study of chronic wound-related pain and itching. Ostomy Wound Manage. 2013 Jul;59(7):28-34.

2. Allman RM, Goode PS, Patrick MM, Burst N, Bartolucci AA. Pressure ulcer risk factors among hospitalized patients with activity limitation. JAMA. 1995 Mar 15;273(11):865-70. https://doi.org/10.1001/jama.1995.03520350047027

3. Rondas AA, Schols JM, Stobberingh EE, Halfens RJ. Prevalence of chronic wounds and structural quality indicators of chronic wound care in Dutch nursing homes. Int Wound J. 2013 Dec 1;12(6):630-5. https://doi.org/10.1111/iwj.12172

4. Wildeboer D, Hill KE, Jeganathan F, Williams DW, Riddell AD, Price PE, Thomas DW, Stephens P, Abuknesha RA, Price RG. Specific protease activity indicates the degree of Pseudomonas aeruginosa infection in chronic infected wounds. Eur J Clin Microbiol Infect Dis. 2012 Sep 1;31(9):2183-9. https://doi.org/10.1007/s10096-012-1553-6

5. Takahashi PY, Kiemele LJ, Jones JP. Wound care for elderly patients: advances and clinical applications for practicing physicians. Mayo Clin Proc. 2004 Feb 29;79(2):260-7. https://doi.org/10.4065/79.2.260

6. Walshe C. Living with a venous leg ulcer: a descriptive study of patients' experiences. J Adv Nurs. 1995 Dec 1;22(6):1092-100. https://doi.org/10.1111/j.1365-2648.1995.tb03110.x

7. Bergin S, Wraight P. Silver based wound dressings and topical agents for treating diabetic foot ulcers. The Cochrane Library; 2006 Jan 1, https://doi.org/10.1002/14651858.cd005082.pub2

8. Hansson C. Interactive wound dressings. Drugs Aging. 1997 Oct 1;11(4):271-84. https://doi.org/10.2165/00002512-199711040-00003

9. Pieper B, Szczepaniak K, Templin T. Psychosocial adjustment, coping, and quality of life in persons with venous ulcers and a history of intravenous drug use. J Wound Ostomy Continence Nurs. 2000 Jul 1;27(4):227-37.

https://doi.org/10.1097/00152192-200007000-00006

10. Gorecki C, Brown JM, Nelson EA, Briggs M, Schoonhoven L, Dealey C, Defloor T, Nixon J. Impact of pressure ulcers on quality of life in older patients: a systematic review. J Am Geriatr Soc. 2009 Jul 1;57(7):1175-83. https://doi.org/10.1111/j.1532-5415.2009.02307.x

11. Fruitman DS, MacDougall CE, Ross DB. Cardiac surgery in octogenarians: can elderly patients benefit? Quality of life after cardiac surgery. Ann Thorac Surg. 1999 Dec 31;68(6):2129-35. https://doi.org/10.1016/s0003-4975(99)00818-8

12. Wilson IB, Cleary PD. Linking clinical variables with healthrelated quality of life: a conceptual model of patient outcomes. JAMA. 1995 Jan 4;273(1):59-65. https://doi.org/10.1001/jama.1995.03520250075037

13. Piaggesi A, Baccetti F, Rizzo L, Romanelli M, Navalesi R, Benzi L. Sodium carboxyl-methyl-cellulose dressings in the management of deep ulcerations of diabetic foot. Diabet Med. 2001 Apr 1;18(4):320-4. https://doi.org/10.1046/j.1464-5491.2001.00466.x

14. Jeffcoate WJ, Price PE, Phillips CJ, Game FL, Mudge EJ, Davies S, Amery CM, Edmonds ME, Gibby OM, Johnson AB, Jones GR. Randomised controlled trial of the use of three dressing preparations in the management of chronic ulceration of the foot in diabetes. Health Technol Assess. 2009;13(54): 1-24. https://doi.org/10.3310/hta13540

15. Spilsbury K, Nelson A, Cullum N, Iglesias C, Nixon J, Mason S. Pressure ulcers and their treatment and effects on quality of life: hospital inpatient perspectives. J Adv Nurs. 2007;57(5): 494-504. https://doi.org/10.1111/j.1365-2648.2006.04140.x

16. Sánchez HM, Muñoz VJ, Roldan MB, Cardo JE, Rivilla FD, de la Calle OA, Cuñarro AJ. Treatment using a hydrocolloid dressing and its influence on the life quality a patient has. Rev Enferm (Barcelona). 2008 Jan;31(1):32-8.

\section{Sažetak}

\section{PRIMJENA HIDROKOLOIDNIH OBLOGA U LIJEČENJU KRONIČNIH RANA I ODNOS S KVALITETOM ŽIVOTA}

\section{Jurić Vukelić i J. Jurić}

Cilj istraživanja bio je analizirati odnos između primjene hidrokoloidnih obloga i tijeka oporavka u bolesnika s kroničnim ranama te kvalitete života. U istraživanju je sudjelovalo 33 ambulantnih vaskularnih bolesnika. Autorice su izradile upitnik za procjenu stupnja u kojem kronična rana ometa svakodnevno funkcioniranje i kvalitetu života. Sudionici su procijenili razinu boli uzrokovane kroničnom ranom, stupanj smanjene samostalnosti u svakodnevnim aktivnostima, stupanj u kojem im kronična rana ometa san te održavanje higijene i stupanj u kojem kronična rana uzrokuje neugodan miris te svoj stupanj povjerenja u pozitivan ishod terapije. Usporedbom odgovora u upitniku prije i nakon primjene hidrokoloidnih obloga utvrđene su značajne razlike u svim aspektima interferencije kronične rane s kvalitetom života: značajno smanjen stupanj boli $(\mathrm{t}(23)=4,14)$, povećana samostalnost u svakodnevnim aktivnostima $(\mathrm{t}(23)=5,01)$, smanjen stupanj u kojem kronična rana ometa san $(\mathrm{t}(23)=3,89)$ i održavanje higijene $(\mathrm{t}(23)=3,00)$ te značajno manji stupanj neugodnog mirisa $(\mathrm{t}(23)=3,66)$ (sve $\mathrm{p}<0,01)$. Nakon primjene hidrokoloidnih obloga zabilježeno je smanjenje svih simptoma povezanih s kroničnom ranom te značajno viša kvaliteta života procijenjena prilikom druge primjene upitnika.

Ključne riječi: Zavoji, hidrokoloidni; Kvaliteta života; Rane i ozljede; Rana, cijeljenje 